\title{
On Irony in Pride and Prejudice from the Perspective of Pragmatic Presupposition
}

\author{
Xuejiao Zhu \\ School of Humanities and Education, Foshan University, Foshan, Guangdong, China
}

\begin{abstract}
Presupposition, as a pragmatic concept, plays an important role in discourse construction. Pragmatic presupposition works inside and outside ironic discourse to help maintain cohesion and coherence as well as direction and integrity of it. This paper presents pragmatic analyses on irony selected from Pride and Prejudice with different functions of presuppositions from social standards, collusive agreement, physical situation, and previous circumstances, and hopes to provide a different way of theorizing irony and ironic discourse.
\end{abstract}

Keywords: Pragmatic presupposition, Irony, Ironic discourse.

\section{Introduction}

Jane Austen is an important name that will certainly come to mind when talking about irony, a rhetoric device of which many studies of value have been shifted from aesthetics of discrepancy in literature to mechanisms of humor in linguistics. It's only natural that irony has become a newly developing interdisciplinary topic.

Presupposition is something which communicators tacitly assume to be the background knowledge in order for smooth and successful communication, thus it is an important tool in discourse research. Therefore, presupposition may provide a new perspective for the study of ironic discourse.

This paper uses pragmatic presupposition to analyze irony and ironic discourse in Pride and Prejudice, based on different functions of presuppositions from social standards, collusive agreement, physical situation, and previous circumstances, and the two characteristics - appropriateness and mutual knowledge - of presupposition. And finally, this study finds that pragmatic presupposition has definitive and contributive organizational function for ironic discourse both in meaning and in structure.

\section{Defining Pragmatic Presupposition}

The study of presupposition in linguistics mainly falls within semantics and pragmatics. Semantic presupposition (SP), which is derived from logical semantics, is 'an inference of proposition whose truth is taken for granted in the utterance of a sentence' (Huang, 2007). That is to say, SP is a logical concept which discusses 'truth value conditions among sentences or propositions' (Zhang, 2009), thus it is structure-sensitive and does not change with context: for example, My wife is/is not a doctor. > I have a wife.

Obvious limitations can be seen when studying presupposition only from the perspective of logic and semantics. Since the 1960s, linguists have started research into presupposition from the perspective of pragmatics. Yule (1996) redefines presupposition as 'something the speaker assumes to be the case prior to making an utterance'. To sum up the views of other various linguists, pragmatic presupposition (PP) is based on semantic presupposition but added with people and environment when using the language (extra linguistic situation), so PP is more about the presupposition of speech act or propositional attitude. In other words, PP concerns not only actual information, whether true or false, but also expectations, desires, claims, attitudes towards the world, fears and beliefs, and so on; thus it is context-sensitive and related to felicity conditions.

\subsection{Why Choose Pragmatic Presupposition?}

From the above explanations, we can see that the study of pragmatic presupposition is not confined within the analysis of semantic relationship between propositions but goes far beyond that. Focusing only on semantic presupposition is closed, static and abstract, whereas the study of pragmatic presupposition requires a dynamic, specific and open context in connection with the communicators' beliefs and background knowledge, which also is the essence of pragmatic presupposition.

\subsection{What can be Pragmatically Presupposed?}

Anything that constitutes an integral part of the production of an utterance is presupposed, or what is necessary to the comprehension of an utterance is what has been presupposed, including (but not limited to): the existence of certain referents, states of affairs, beliefs and values, intentions and desires.

\section{Characterizing Pragmatic Presupposition}

Pragmatic-logically speaking, the analysis of presupposition properties can be carried out in two aspects: appropriateness and mutual knowledge (Levinson, 1983).

\subsection{Appropriateness}

Austin (1962) was the first linguist who attempted an analysis of appropriateness and inappropriateness, and proposed theories about the conditions for performing a speech act felicitously to start with. Recent literature summarize the appropriateness of presupposition as the presupposition of utterance being congruous and consistent with a certain context, which is a prerequisite for successful communication. It is worth noting that this appropriateness needs to be interpreted with both 'the speaker's taking into account the appropriate context when speaking' and 'the listener's 
understanding the utterance within the aforementioned context'. For example:

\author{
A: May I have this dance, my lady? \\ B: My pleasure, my lord. \\ A: Hey bro, fifty bucks, now. \\ B: Gee there you go.
}

It can be seen from the above two dialogues that the presupposition of context, whether questioning or answering, is appropriate. The first set obviously may take place in Royal court, while the second set can happen within family members or other intimate brotherly relations. Moreover, the interlocutors in the two sets are well informed of the context they are currently in.

The appropriateness of presupposition is most noticeable when considered in coordination with context. Only when we pay attention to the appropriateness of presupposition can we achieve communicative purposes effectively. Specifically speaking, in order for presupposition to be understood by interlocutors, certain contextual conditions must be met: such as age, gender and identity of the participants, the kinship and status between them, the situation of relevant persons and other objective background, and the like. It is not until these conditions are met that the 'speech act' in a certain context can be expected to be meaningful, suitable and acceptable.

\subsection{Mutual Knowledge}

The mutual knowledge of presupposition refers to the background knowledge that is acceptable and comprehensible to both sides of communication. With a statement - 'An utterance A pragmatically presupposes a proposition B if A is appropriate only if B is mutually known by participants.'- the concept of background beliefs was first introduced by Levinson (1983). For example:

\section{A: It's raining cats and dogs outside! \\ B: We can't go back home now.}

In the above dialogue, both sides presuppose 'time to leave school' as background information in order for the communication to go smoothly.

He (1988) further developed mutual knowledge of presupposition and interpreted it in three dimensions:

- Presupposition is often the information shared by both sides of the conversation or among ordinary people (i.e., common sense), and it is closely combined with the context.

- The mutual knowledge of presupposition should be revealed through the speaker's discourse and understood by the listener.

- The mutual knowledge of presupposition is sometimes limited to both sides of the conversation, whereas other people, due to lack of this presupposition, can only understand the superficial meaning rather than the real meaning of the conversation. For example:
A: It's raining cats and dogs outside AGAIN?

B: We can't go see the lake, AGAIN!

In the above dialogue, both sides presuppose 'travel plan' as mutual knowledge in advance known exclusively to themselves and other people may not fully understand why they get so frustrated about the heavy rain.

\section{Classification of Pragmatic Presupposition}

So far three scholars have given different classifications to pragmatic presupposition in China, but common ground has not been achieved. Chen (1998) divided PP into fact presupposition, belief presupposition, state presupposition and behavior presupposition. Wei (2003) added culture presupposition and pun presupposition to Chen's categories. Since pragmatic presupposition can be classified according to various situations, Yang (2013), based on constructive functions of PP in ironic discourses, put forward a new classification in terms of social norms presupposition, collusive presupposition, mutual manifest presupposition of the physical environment and dynamic and progressive presupposition. The author of this paper favors Yang's system, which is shown more clearly in the table below, and will adopt her classification to do further analyses.

Table 1: Yang's classification of pragmatic presupposition

\begin{tabular}{|c|c|}
\hline Categories: & Contents majorly concerning: \\
\hline social norms presupposition & social conventions \\
\hline collusive presupposition & $\begin{array}{l}\text { background information known } \\
\text { exclusively to participants }\end{array}$ \\
\hline $\begin{array}{l}\text { mutual manifest presupposition of } \\
\text { the physical environment }\end{array}$ & salient physical environment \\
\hline $\begin{array}{c}\text { dynamic and progressive } \\
\text { presupposition }\end{array}$ & $\begin{array}{l}\text { new information built on old } \\
\text { information }\end{array}$ \\
\hline
\end{tabular}

\section{On Irony from the Perspective of Pragmatic Presupposition}

\subsection{Irony and Ironic Discourse}

Irony is a literary device which employs contradictory statements or conflicting situations to reveal a reality that is different from what appears to be true. There are many forms of irony featured in literature. The four most frequently discussed are verbal irony, situational irony, structural irony and mode irony. The effectiveness of irony depends on the reader's expectations and understanding of the disparity between what 'should' happen and what 'actually' happens in a literary work. This can be an unforeseen outcome of an event, a character's unexpected behavior, or something incongruously said.

One of the most prominent features of ironic discourse is the 'discrepancy' between semantics and pragmatics. It is the key to the identification of irony, which is embedded in all aspects of ironic discourse. This 'gap' (i.e., discrepancy) can manifest itself in the incompatibility between the propositional meaning and the context, the incongruity between reality and anticipation, or the inconsistency between the literal and implied meaning. 


\subsection{What Role Does Pragmatic Presupposition Play in Ironic Discourse?}

The social, cognitive and contextual 'setting' beyond the discourse (extra linguistic situation), which is assumed to be mutually and appropriately known to both sides of communication, forms the basis and information source of the construction of ironic discourse. This 'background information' hidden behind language performs as pragmatic presupposition (PP) for the cohesion and coherence in ironic discourse to help construe and comprehend irony in order for effective communication. Moreover, PP resides in every interactive process which constitutes the space for ironic discourse development and stipulates the direction of that development. This directly affects the 'linking up' in meaning and 'building up' in structure. In sum, pragmatic presupposition has definitive and contributive organizational function for ironic discourse.

\subsection{Case Analyses Selected}

Jane Austen is a master with irony whose 'golden ironic touch' rendered ordinary things and characters extraordinary. Her exquisite treatment of domesticity and her drawing room conversations laced with philosophy are enough to fascinate generations after generations. Pride and Prejudice centers around courtships and marriages between eligible bachelors and single ladies. Yet she wrote with characteristic modesty, 'How could I join them (men) on to the little bit (two inches wide) of ivory on which I work with so fine a brush, as produces little effect after much labour?' Jane obviously has countless published papers from countless scholars fed on her works (including the author of this paper of course) to do her justice.

\subsubsection{Social norms presupposition}

Ironic discourse is of best effect when irony is used to remind of certain antecedent expectations, social conventions, or shared standards which get violated to some extent (cf. Glucksberg 1995:53). A speech act concerning deep-rooted social norms and regional cultural customs does not entail any ready-made meaning, but serves as pragmatic presupposition triggers to activate various judgement from all corners, thus producing humorous ironic results.

'It is a truth universally acknowledged, that a single man in possession of a good fortune, must be in want of a wife.

However little known the feelings or views of such a man may be on his first entering a neighbourhood, this truth is so well fixed in the minds of the surrounding families, that he is considered as the rightful property of some one or other of their daughters.' (Austen 2002:7)

Primogeniture is a widely adopted practice in Europe in Jane Austen's time. It is the right, by law or custom, of the firstborn male child to inherit the family estate, in preference to siblings. Moreover, in English common law, entail is a form of trust established by deed or settlement which restricts the sale or inheritance of an estate in real property and prevents the property from being sold, devised by will, or otherwise alienated by the tenant-in-possession, and instead causes it to pass automatically by operation of law to an heir pre-determined by the settlement deed.

To put it in a nutshell, as far as the Bennet family (no male offspring, five daughters though) concerns, none of the girls is entitled to inherit the landed estate or the income heavily dependent on the estate. It will all fall into the hands of a male heir (in this case, Mr. Collins) no matter how remotely related he is to the family. This basic norm about patriarchal society that a woman's happiness was mostly hinged upon the properties of the man she was to marry presupposes Mrs. Bennet to eagerly marry off her daughters for much-needed financial stability.

Words like 'universally' and 'must' are used to enhance the absoluteness, the indisputable truth of the statement - a wealthy young bachelor has to marry in order for survival. However, the pragmatic presupposition here is quite the opposite - a single young lady in possession of a small fortune, must be in want of a wealthy husband.

Phrases such as 'so well' and 'rightful property' convey the implied emotion as if these eligible young men, by social customs or national law, should be possessed by these daughters. No logic whatsoever can be applied to this shared belief which is deeply presupposed around the neighborhood.

\subsubsection{Collusive presupposition}

Some discourses only employ background knowledge mutually and exclusively known to both sides of communication (the insiders) as pragmatic presupposition, especially in some specific context where collusive and encrypted activities are carried out. Comic irony comes into shape when 'the outsiders' cannot fully grasp the presupposition.

'Mr. Collins had only to change from Jane to Elizabeth - and it was soon done - done while Mrs. Bennet was stirring the fire. Elizabeth, equally next to Jane in birth and beauty, succeeded her of course.' (Austen 2002:85)

'My reasons for marrying are, ... and thirdly - which perhaps I ought to have mentioned earlier, that it is the particular advice and recommendation of the very noble lady whom I have the honour of calling patroness.' (Austen 2002:125)

Mr. Collins is the heir to Longbourne - the estate of the Bennets' household. He decided to probably marry one of the daughters to 'compensate for their loss'. His first choice was Jane, but knowing that Jane was soon to marry someone else he changed his mind, but all too quickly - Elizabeth was his next candidate.

Mr. Collins does not care if his other half is strikingly beautiful or has a profound mind or anything for that matter. What matters to him is that Elizabeth is the second daughter in line, which makes her his second option.

The tacit understanding that Lady Catherine (Mr. Collins' patroness) wants him to get married in the first place acts as the pragmatic presupposition so collusive between these two parties that all marriageable qualities - treating the other half as a 'person' rather than as an object to begin with - are totally 
oblivious to Mr. Collins. His blatant act to get a wife successfully is mission accomplished to his patroness, Lady Catherine, who is his first and foremost priority to do anything and his real motive to marry just anyone indeed. This explains why Elizabeth pulled a wry face by Mr. Collins' ridiculous, unreasonable, hypocritical, overly-confident proposal which borders on insulting offence, in that she, as a sensible 'outsider', would never fully comprehend the master-servant relationship exclusively held by the stupid, impenetrable duo.

5.3.3 Mutual manifest presupposition of the physical environment

Cognitive context is a complex mechanism which encompasses a wide range of physical environment, psychological schema, social knowledge, cultural proposition and so on. Among them, the mutual explicit physical environment shared by both sides of communication can be activated as pragmatic presupposition in ironic discourse. When the participants' verbal acts or non-verbal gestures are deliberately not in accordance with or even ostensibly agree with the physical environment, they might intend for them to be interpreted as an irony to some degree. In other words, the participant consciously deviates from the facts (physical reality) to assert his or her ironic statement.

'What can be the meaning of this [Darcy's frequent visits]!' said Charlotte, as soon as he was gone. 'My dear Eliza he must be in love with you, or he would never have called on us in this familiar way.'

But when Elizabeth told of his silence [Darcy was extremely taciturn when being with Elizabeth], it did not seem very likely, even to Charlotte's wishes, to be the case; and after various conjectures, they could at last only suppose his visit to proceed from the difficulty of finding any thing to do, which was the more probable from the time of year. (Austen 2002:210)

This was during wintertime when there was nothing recreational for gentlemen and ladies to do. This cognitive context (wintertime) presupposes the manifest physical environment to participants of communication.

Darcy paid frequent visits to Elizabeth during her stay at Hunsford Parsonage. Neither Charlotte nor Elizabeth could figure out why this young gentleman would come to visit them at all. The only explanation they could think of was that Mr. Darcy had nothing better to do. However, what Elizabeth did not know was that Mr. Darcy had a growing attachment to her! - for all the reserved affection - the real reason for his frequent visits, of which the readers are well aware, is that Darcy is going to propose to her just in several days' time. The dramatic 'discrepancy' between 'nothing to do' and 'only to propose' is shown in sharp contrast in this ironic discourse.

'Mr. Bennet, ... You take delight in vexing me. You have no compassion on my poor nerves.'

'You mistake me, my dear. I have a high respect for your nerves. They are my old friends. I have heard you mention them with consideration these twenty years at least.' (Austen 2002:9)
'When she was discontented, she fancied herself nervous' (Austen 2002:10) was the manifest physical situation presupposed by Mrs. Bennet herself in the Bennets' household. She had repeated the term so many times that her 'poor nerves' have already become Mr. Bennet's 'old friend'. Since normally, one can only have respect and compassion for an old acquaintance, Mr. Bennet's conscientiously unconcerned response to his wife shows that he is actually the least altered by her complaint, which highlights the irony in the discourse.

In addition, the source of the term comes from the development of medicine at that time. Previously, human beings in Europe had believed that it was the four humors (phlegm for brain, blood for heart, black bile for spleen, yellow bile for liver) that decided bodily processes. In the 18th century, scientists found the existence of nerves and began to explore their function and developed new theories to explain corporal conditions, which serves as the macro physical presupposition for the scene. Thus, it has become the fashion for people like Mrs. Bennet to 'jump at' such a new and mysterious term to complain about her health. Ironically, her frequent use of the word 'nervous' helps the readers to penetrate into her peanut-sized, uncertain brain to appreciate her insufficient, yet laughable character.

\subsubsection{Dynamic and progressive presupposition}

Information comes from the progressive alteration from the old to the new (cf. Halliday 1985: 274-275). Both sides of communication presuppose the previously known information as background for exchanging new propositions. Ironic discourse has flowing linear feature in itself where through multiple superimposition of information the new one constantly becomes the focus. In this dynamic process, both the speaker and the listener take the presupposed information inserted within words, acts, or intonations for granted to move on with their communication to achieve ironic effect.

'Oh! Mr. Bennet, ... You must come and make Lizzy marry Mr. Collins, ... if you do not make haste he will change his mind and not have her.' [Mrs. Bennet]

... 'I have not the pleasure of understanding you,' said he, ... 'Of what are you talking?'

... 'And what am I to do on the occasion? - It seems an hopeless business.'

... 'Let her be called down. She shall hear my opinion.' [Mr. Bennet]

... 'Come here, child,' cried her father as she appeared. 'I have sent for you on an affair of importance. I understand that Mr.Collins has made you an offer of marriage. Is it true?' Elizabeth replied that it was. 'Very well - and this offer of marriage you have refused?'

'I have, Sir.' [Elizabeth]

'Very well. We now come to the point. Your mother insists upon your accepting it. Is not it so, Mrs. Bennet?'

'Yes, or I will never see her again.' [Mrs. Bennet]

'An unhappy alternative is before you, Elizabeth. From this day you must be a stranger to one of your parents. - Your mother will never see you again if you do not marry $\mathrm{Mr}$. Collins, and I will never see you again if you do.' (Austen 2002:132) 
Throughout the novel, what has been presupposed as background information was that Mr. Bennet did not play his role as a father or a husband dutifully most of the time. It was not until the elopement of his youngest daughter Lydia that he came to realize the importance of money - in the respect that honor and credit for a young woman could be purchased. All that being said, nonetheless, Elizabeth had always been his favorite daughter; and in this round of dealing with an unreasonable mother, he accomplished his intervention beautifully.

By constant superimposition of new propositions one by one fake ignorance of the situation, apathy in the desperate business, ostentatious lecture on disobedience, specious advice of a paradoxical alternative - the old and new presuppositions are repeatedly integrated, from the known to the unknown, in such a skillful way that he supported Elizabeth strongly and refuted his wife mercilessly. Everyone was amusingly satisfied with such a quick conclusion at such a chaotic beginning, except Mrs. Bennet who was left too frustrated to ever realize the absurdity of this ironic event.

\section{Conclusion}

Communicators dexterously manage through twists and turns in the construction of ironic discourse using various presuppositions. Pragmatic presupposition works outside by attaching itself to explicit language forms (concrete linguistic units such as words, sentences, intonations), and also works inside by inserting itself within implicit cognitive context (abstract extra-linguistic situations such as social awareness, information environment), which helps build up the cohesion and coherence of the discourse and keep up the direction and integrity in it. This paper pragmatically analyses the irony in Pride and Prejudice with different functions of presuppositions from social standards, collusive agreement, physical situation, and previous circumstances. The author hopes to provide one more way of thinking to appreciate the delicious caprice, magnetic rationality and profound wisdom in Jane Austen's works.

\section{References}

[1] Austin, J. How to Do Things with Words[M]. Oxford: Oxford University Press, 1962.

[2] Glucksberg, S. Commenting on Nonliteral Language: Processing and use[J]. Metaphor and Symbolic Activity, 1995(1): 47-57.

[3] Goffman, E. Frame Analysis: An Essay on the Organization of Experience[M]. New York: Harper \& Row, 1974.

[4] Goffman E. Felicity's Condition[J]. American Journal of Sociology, 1983, 89(1): 1-53.

[5] Halliday, M. A. K.. An Introduction to Functional Grammar[M]. London: Hodder Arnold, 1985.

[6] Huang, Y. Pragmatics[M]. Oxford: Oxford University Press, 2007.

[7] Levinson, S. Pragmatics[M]. Cambridge: Cambridge University Press, 1983

[8] Searle, J. R. A Classification of Illocutionary Acts[J]. Language in Society, 1976, 5(1), 1-23.

[9] Yule, G. Pragmatics[M]. Cambridge: Cambridge University Press, 1996.
[10] Chen Xinren. On Pragmatic Presupposition in Advertising Language [J]. Foreign Languages, 1998 (5): 54-57.

[11] He Ziran. Introduction to Pragmatics [M]. Changsha: Hunan Education Press, 1989.

[12] Wei Zaijiang. Multidimensional Thinking on Presupposition Research [J]. Foreign Language Teaching, 2003 (3): 32-35.

[13] Yang Jun. On Four Types of Irony in Novels [J]. Academic Exchange, 1994 (06): 64-68.

[14] Yang Qingyun. Pragmatic Presupposition and the Construction of Ironic Discourse [J]. Foreign Language Teaching, 2013 (06): 25-29.

[15] Zhang Jiahua. Semantic Presupposition: A Perspective of Pragmatic Presupposition [J]. Journal of Foreign Languages, 2009 (3): 70-75.

[16] Online Dictionary. https://useenglishwords.com/entail/ item 13 [Accessed: June. 12, 2021]

\section{Author Profile}

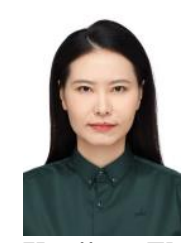

Xuejiao Zhu received the Bachelor of Arts degree in English language and Literature from Industrial and Commercial College, which is affiliated to Hebei University, Baoding, and is studying for the Master degree in English Education in Foshan University, Foshan, China now. She is also currently working with the view of the Ph.D. degree in Language Education. Her research interests include English language and Literature, English Education for ESL learners, and Washback studies. 